Maciej GrochowsKi

\title{
Między składnią semantyczną a asemantyczną, czyli o wpływie Henryka Misza i Zygmunta Saloniego na poglądy składniowe Krystyny Kallas
}

Słowa klucze: współczesny język polski, składnia, semantyka, Krystyna Kallas, Henryk Misz, Zygmunt Saloni

1. Profesor Krystyna Kallas dnia 16 września 2010 roku skończyła siedemdziesiąt lat. Z tej okazji Instytut Języka Polskiego Uniwersytetu Mikołaja Kopernika w Toruniu zorganizował cztery dni później sesję naukową dedykowaną Jubilatce, wyrażając Jej szacunek i wdzięczność za bez mała pół wieku twórczej pracy naukowej i dydaktycznej, a także za liczne dokonania organizacyjne w Uniwersytecie. Na zakończenie tej sesji, przedstawiając osiągnięcia naukowe Krystyny Kallas w zakresie składni, podjąłem próbę określenia stosunku dorobku Uczonej do głównych nurtów współczesnej składni polskiej. Na poglądy składniowe Krystyny Kallas niewątpliwie największy wpływ miały koncepcje metodologiczne Henryka Misza i Zygmunta Saloniego. Określenie miejsca prac syntaktycznych Krystyny Kallas w językoznawstwie polskim wymaga więc uwzględnienia oddziaływań obu Uczonych na dorobek Jubilatki. 
2. Niestandardowe sformułowanie tytułu tego artykułu nie jest lapidarne, a mimo to wymaga pewnego komentarza. Takie ujęcie tytułu jest oparte na dwóch ogólnych przesłankach.

Przesłanka pierwsza. Podstawowym zadaniem składni jest ustalanie zasad łączenia wyrażeń prostych w wyrażenia złożone (w szerokim sensie: wraz z linearyzacją struktur i ich składników), a także ustalanie zasad budowy wyrażeń złożonych. W realizacji tych zadań powinien być brany pod uwagę aksjomat, że wyrażenia są jednostkami bilateralnymi (w sensie Saussure'owskim; Saussure 1991, 2004), a więc że formy językowe są reprezentantami pojęć. Metodologia składni przyjmująca taki punkt widzenia w postępowaniu badawczym jest inwariantem wszystkich koncepcji składni semantycznej. Teorie składniowe, które stawiają przed sobą wymienione na samym początku zadania, ale postulują ich realizację w abstrakcji od komponentów treściowych form językowych, nazywam ogólnie asemantycznymi. Oba terminy tytułowe, składnia semantyczna i asemantyczna, mają szeroką i nieostrą denotację, odnoszą się do różnych teorii i szkół (por. np. Karolak 1972, 2002, a ostatnio m.in. Linde-Usiekniewicz 2008, Szumska 2010, Willim 2010), dla dalszych rozważań uściślanie tych terminów nie jest jednak konieczne.

Przesłanka druga. Badania naukowe są procesem ciągłym. Każda koncepcja, a nawet hipoteza naukowa jest zdeterminowana wartością parametru czasu i jako taka opiera się na zaakceptowanych już koncepcjach, zweryfikowanych hipotezach albo na ich negacji. Jedną z podstawowych zasad Popperowskiej (Popper 1977, 1992) metodologii ogólnej nauk jest świadomość wszystkich zastanych koncepcji rozwiązywania danego problemu badawczego przed przystąpieniem do jego ponownego badania. Tak więc oddziaływanie prac naukowych jednych badaczy na prace innych badaczy nie tylko należy do standardowych praw rozwoju nauki (Kuhn 1968, Chalmers 1993), ale jest warunkiem sine qua non postępu naukowego, a tym samym cywilizacyjnego. Sposób użycia jednostki wpływ na w tytule tego artykułu wynika z wyłuszczonej pokrótce przesłanki. Jednostka ta odnosi się wyłącznie do prac naukowych autorstwa wymienionych w tytule lingwistów, a nie do samych tych uczonych. Również mówiąc o poglądach Krystyny Kallas, mam na myśli wyłącznie jej poglądy składniowe (co wynika już z drugiego słowa tytułu), odzwierciedlone w jej dorobku twórczym. 
3. Prezentacja głównych tez tego artykułu wymaga podania przynajmniej krótkiej informacji o dorobku naukowym Krystyny Kallas i o miejscu składni w jej dorobku.

Przedmiotem badań naukowych Krystyny Kallas jest gramatyka współczesnego języka polskiego, w szczególności składnia i słowotwórstwo, a ponadto stylistyka językoznawcza. Spośród z górą pięćdziesięciu artykułów naukowych, opublikowanych w ciągu półwiecza (Krystyna Kallas zadebiutowała w 1961 roku Metaforyka wierszy Juliana Przybosia (Kallas 1961)), ponad trzydzieści poświęciła składni, niektóre prace łączą zagadnienia słowotwórcze ze składniowymi i/lub stylistycznymi; składni dotyczą wszystkie trzy monografie książkowe Jubilatki. Pierwszym zagadnieniem składniowym, któremu Krystyna Kallas poświęciła pierwszych kilka lat pracy naukowej, była zhierarchizowana, czteropoziomowa, klasyfikacja formalna polskich zdań pojedynczych nierozwiniętych. W wyniku rozległych badań empirycznych struktur typu Noc., Cisza., Mgła., Czas to pieniądz., Żyć to pracować., Pachnial wiatr i morze., Andrzej i Amelia milczeli., zależności formalnych między ich komponentami, a także związków z kontekstem zewnętrznym, powstała w 1970 roku rozprawa doktorska Próba klasyfikacji zredukowanych zdań pojedynczych dzisiejszej polszczyzny pisanej (jej promotorem był prof. Leszek Moszyński), która stała się podstawą pierwszej monografii składniowej Krystyny Kallas (1974). Drugim wielkim problemem składniowym, dominującym w działalności twórczej Uczonej w drugiej połowie lat 70. XX wieku, były konstrukcje apozycyjne we współczesnym języku polskim i ich wewnętrzna struktura formalnogramatyczna. Krystyna Kallas w poświęconej im monografii (1980), na podstawie której uzyskała stopień doktora habilitowanego, zbadała ponadto szyk członów grupy apozycyjnej i jego konsekwencje komunikacyjne, relacje między znaczeniami członów grupy, a także między komponentami apozycji a ich denotatami. W latach 80. i na początku lat 90. XX wieku badania składniowe Krystyny Kallas koncentrowały się na analizie konstrukcji współrzędnych, a dotyczyły przede wszystkim hierarchii komponentów konstrukcji, ich dystrybucji, zależności konotacyjnych i akomodacyjnych oraz związków linearnych. Zagadnienia te omówiła Uczona w swojej trzeciej monografii (Kallas 1993). Rozważania o współrzędności stanowiły dogodny punkt wyjścia do analizy wielu wyrażeń funkcyjnych, nie tylko wykładników tej relacji. W latach 80., 90. XX wieku i jeszcze na samym początku XXI wieku Krystyna Kal- 
las opublikowała liczne artykuły poświęcone właściwościom składniowym spójników, przyimków i zaimków. Spośród tych publikacji da się wyodrębnić dwie serie, większą dotyczącą wykładników konstrukcji porównawczych, koncentrującą się na analizie ciągu o kształcie niż (por. Kallas 1995, 1997a, 1997b, 1998a) i mniejszą, związaną z kategorią negatywności, dotyczącą ciągów o kształcie ani (Kallas 1994) oraz zaimków przeczących (1998b). Badania słowotwórcze (i zdecydowanie rzadziej stylistyczne) Krystyna Kallas prowadziła równolegle do składniowych, pierwszą dekadę XXI wieku poświęciła niemal wyłącznie słowotwórstwu. Jest autorką syntezy słowotwórstwa przymiotników, opublikowanej jako rozdział w znanym, wydanym trzykrotnie (1984, 1998, 1999), podręczniku Gramatyka współczesnego języka polskiego. Morfologia (Kallas 1984).

Tytuł naukowy profesora otrzymała Krystyna Kallas w 1994 roku. W czterdziestolecie działalności twórczej została uhonorowana dedykowanym Jej zbiorem prac Studia z gramatyki i semantyki języka polskiego (Moroz, Wiśniewski (red.), 2004).

4. Podstawą formułowanych tutaj tez, z konieczności bardzo ogólnych, ale potwierdzonych odsyłaczami do dorobku naukowego Uczonej, są przede wszystkim trzy monografie składniowe Krystyny Kallas (1974, 1980, 1993).

Teza pierwsza jest następująca. Dorobek syntaktyczny Krystyny Kallas sytuuje się pod względem metodologicznym w miejscu wskazanym w tytule artykułu, to znaczy między składnią semantyczną a asemantyczną. Analiza właściwości składniowych form językowych i ich połączeń zdecydowanie dominuje w pracach Uczonej, niemniej jednak rozważań nad problemami z zakresu składni semantycznej Krystyna Kallas nie unika.

Monografia o grupach apozycyjnych tylko częściowo dotyczy zagadnień składni formalnej. Jej Autorka poszukując w pracy tej odpowiedzi na pytanie o ekwiwalencję funkcjonalną konstrukcji apozycyjnych i par zdań, z których konstrukcje takie są derywowane, dochodzi do wniosku, że brak jest z reguły jedno-jednoznacznej korelacji między bazą transformacyjną a transformą (Kallas 1980: 115). Z kolei analizując pozycję linearną członów konstrukcji apozycyjnej, a także pozycję konstrukcji (jako całości) w strukturze wypowiedzenia, bada podzielność apozycji na jednostki struktury tematyczno-rematycznej, a także określa miejsce grupy apozycyjnej jako całości W strukturze tematyczno-rematycznej wypowiedzenia. W toku analizy zda- 
je sprawę z tego, że struktura tematyczno-rematyczna jest strukturą hierarchiczną (Bogusławski 1977), a więc mającą wewnętrzne rozczłonkowanie na analogiczne jednostki niższego rzędu (Kallas 1980: 126). Przyjmując założenia klasycznej semantyki strukturalnej, mianowicie że leksemom przysługuje sens i denotacja (Lyons 1977), a także korzystając z podstaw logicznej teorii zbiorów, Krystyna Kallas pokazuje, że między członami grup apozycyjnych zachodzą wszystkie teoretycznie możliwe relacje denotacyjne i relacje sensu. W monografii o konstrukcjach współrzędnych w znacznie mniejszym stopniu ujawniają się zainteresowania Uczonej zagadnieniami składni semantycznej, niemniej jednak celowe jest zwrócenie uwagi na dwie myśli wyrażone w ostatnich rozdziałach pracy. Krystyna Kallas (1993: 130-134) uważa, iż kolejność współrzędników może być zdeterminowana znaczeniem danego spójnika, a także znaczeniem wyrażeń stanowiących człony konstytuowanych przez spójnik relacji. W końcowej części monografii Autorka (Kallas 1993: 148-153) rozważa niespójne semantycznie konstrukcje współrzędne, które mogą stanowić źródło gry językowej. Również w niektórych artykułach dotyczących konstrukcji porównawczych omawiane są zagadnienia semantyczno-składniowe. Dla takich konstrukcji istotna jest kwestia jednorodności semantyczno-leksykalnej członów. W związku z tym wybór pierwszego członu konstrukcji tworzonej przez niż determinuje wybór drugiego (Kallas 1997a, 1998a). Opozycja jednorodności i różnorodności leksykalnej jest omawiana także w innych artykułach Krystyny Kallas (1989, 1991), dotyczących m.in. konstrukcji współrzędnych.

5. Na temat drugiej ogólnej tezy tego artykułu wskazuje jego tytuł, mianowicie na istnienie wpływu dorobku syntaktycznego Henryka Misza i Zygmunta Saloniego na Krystyny Kallas sposób podejścia do (ujmowania) składni. Chodzi tu, krótko mówiąc, o determinacje metodologiczne. Biorąc pod uwagę niezależność oddziaływania obu uczonych, a także istotne różnice chronologiczne, tezę tę sformułuję w postaci dwóch odrębnych konstatacji.

Na dorobek naukowy Krystyny Kallas w zakresie składni polskiej - od samego początku działalności badawczej Uczonej przez bez mała dwadzieścia lat, tj. do przełomu lat 70. i 80. XX wieku - miały istotny wpływ koncepcje syntaktyczne Henryka Misza. Wpływ ten od połowy lat 70. stopniowo słabnie.

Oddziaływanie teorii syntaktycznych (ściślej gramatycznych) Zygmunta Saloniego na sposób podejścia Krystyny Kallas do składni ma swój począ- 
tek w drugiej połowie lat 70. XX wieku i ujawnia się w ogromnej liczbie prac syntaktycznych Uczonej do dziś. Próba ustalenia relacji między okresami oddziaływań obu uczonych skłania do wniosku, że okresy te zachodzą na siebie w niewielkim stopniu. Na badania nad grupami apozycyjnymi wpływ już mają prace Zygmunta Saloniego, a jeszcze nie przestają mieć wpływu prace Henryka Misza.

Dążąc do rozwinięcia i udokumentowania drugiej ogólnej tezy tego artykułu, zmienię z dwóch powodów porządek dalszych refleksji, łamiąc ich naturalny układ chronologiczny. Po pierwsze, podstawowe prace ogólne Zygmunta Saloniego z zakresu teorii składni (gramatyki) są powszechnie znane, niektóre z nich, należące do kanonu lektur akademickich, miały wiele wydań. Szczegółowa charakterystyka związków między pracami Zygmunta Saloniego a pracami Krystyny Kallas ze względów czasowych i przestrzennych jest nierealna, a tylko szczegółowa z merytorycznego punktu widzenia miałaby sens, ponieważ samą koncepcję składni formalnej autorstwa Zygmunta Saloniego Krystyna Kallas akceptuje. Dorobek syntaktyczny Henryka Misza (1924-1968), zamknięta karta historii językoznawstwa polskiego, jest znany słabo, zwłaszcza przez pokolenia młodsze. Choć ilościowo bardzo skromny (liczy bowiem około 20 pozycji i obejmuje tylko jedną monografię książkową - Misz 1967; por. pełną bibliografię uczonego, opublikowaną w Misz 1981), w czasach, w których powstawał, wnosił do nauki wiele odkrywczych idei, które dopiero po dziesięcioleciach były rozwijane i zostały docenione (por. np. Wajszczuk 1997, 2005, Grochowski 2009, 2011). Dorobek ten wymaga głębokich studiów w ramach badań nad historią składni strukturalnej. W tym miejscu chciałbym o paru pracach Henryka Misza, mających wpływ na prace Krystyny Kallas, przypomnieć. Po drugie, nie negując rozpowszechnionej opinii, iż prace Misza reprezentują nurt formalny w składni polskiej, uważam, że jego liczne myśli, np. towarzyszące klasyfikacji syntaktemów i „wyrazów bez wartości syntaktycznej” (Misz 1967) czy związane z tzw. psychologicznymi konsekwencjami analizy szyku (Misz 1962, 1966), są bardzo bliskie koncepcjom składni semantycznej, a w każdym razie między składnią semantyczną a asemantyczną mogą być usytuowane. A zatem, jeśli zaaprobuje się tezę pierwszą, to trzeba by zgodzić się z tym, że oddziaływanie prac Misza na prace Kallas, choć znacznie krótsze niż prac Saloniego, nie dotyczyło jedynie asemantycznego podejścia do składni. 
6. Wpływ metodologiczny Zygmunta Saloniego na badania składniowe Krystyny Kallas widoczny jest już w jednym z jej pierwszych artykułów na temat apozycji (Kallas 1978). Autorka wprowadza w nim, opierając się na pracach Saloniego (m.in. Saloni 1976, 1977), aparat składni dystrybucyjnej i analizuje m.in. związki akomodacyjne między członami konstrukcji apozycyjnych. W rozdziale drugim i trzecim monografii o apozycjach (Kallas 1980) Autorka korzysta w analizie struktury syntaktycznej (powierzchniowej i głębokiej) konstrukcji apozycyjnych z metod badawczych przedstawionych w nieopublikowanej jeszcze wtedy wersji znanego podręcznika Zygmunta Saloniego i Marka Świdzińskiego (Saloni, Świdziński 1985), którego pierwsze wydanie ukazuje się już po opublikowaniu monografii o apozycjach. W charakterystyce apozycji jako transform par zdań odwołuje się do aparatu wypracowanego przez Marka Świdzińskiego (1978). Wszystkim pracom składniowym Krystyny Kallas, późniejszym od monografii o apozycjach, narzędzia składni formalnej będą już towarzyszyć jako ich stały atrybut.

7. Wpływ metodologii Henryka Misza na pierwsze prace składniowe Krystyny Kallas, mianowicie na wymienioną już wcześniej jej rozprawę doktorską, cztery artykuły z zakresu problematyki rozprawy oraz na pierwszą monografię (opublikowaną pod nieco innym niż rozprawa tytułem; Kallas 1974), był absolutnie zasadniczy (choć Henryk Misz zmarł dwa lata przed doktoratem Krystyny Kallas, nie był też opiekunem jej pracy magisterskiej). Krystyna Kallas w swojej rozprawie przedstawiającej bardzo szczegółową klasyfikację zdań pojedynczych nierozwiniętych kontynuowała badania Misza, wychodząc od jego rozróżnienia zdań dwuczłonowych (współpodrzędnych i niepodrzędnych) i jednoczłonowych (Misz 1968). Przyjęła jego rozumienie składni wraz z opozycją zdania i grupy syntaktycznej, a także kluczowym dla obu wielkości pojęciem syntaktemu, przyjęła również oryginalną klasyfikację syntaktemów autorstwa Misza (1967), jego koncepcję członu zdania i zaproponowane przez niego zasady podziału zdań pojedynczych (Misz 1968). Dostosowała cały aparat terminologiczny wraz z notacją formuł rejestrujących cechy członów zdań do aparatu i oryginalnej notacji Misza (notabene, notacja tych formuł przypomina aparat gramatyki kategorialnej Kazimierza Ajdukiewicza, 1985). 
Wpływ koncepcji składniowych Henryka Misza na poglądy Krystyny Kallas ujawnia się również, ale już w stopniu znacznie mniejszym, w monografii Uczonej o apozycjach. W rozdziale dotyczącym kolejności członów konstrukcji apozycyjnej Autorka przyjmuje wprowadzone przez Misza (1966), znane z jego prac o szyku, rozpatrywanym w tzw. aspekcie psychologicznym, rozróżnienie członu wyjściowego (cw) i członu rozwijającego (cr) i aplikuje je do analizy grup apozycyjnych występujących w kontekście, zastępując jednak nieużywane w literaturze terminy Misza rozpowszechnionymi, odpowiednio datum i novum (Kallas 1980: 120). Przyjmując milcząco, że rozczłonkowanie to nie pokrywa się z rozczłonkowaniem tematyczno-rematycznym wypowiedzenia, bada to ostatnie w wypowiedzeniach $\mathrm{z}$ apozycjami, ujmując je jako strukturę hierarchiczną, metodami zaproponowanymi przez Andrzeja Bogusławskiego (Bogusławski 1977).

8. Scharakteryzowany na wstępie bardzo ogólnie i w dużym skrócie dorobek syntaktyczny Krystyny Kallas ma wpływ na dokonania wielu innych badaczy składni polskiej, tworzących współcześnie, i będzie miał wpływ na badania ich następców. Z całą pewnością można by zacząć pisać już dziś następny odcinek historii składni polskiej, dotyczący oddziaływania prac Krystyny Kallas na prace innych badaczy. Zadanie takie pozostawiam jednak przedstawicielom młodszych pokoleń językoznawców polskich.

\section{Bibliografia}

Ajdukiewicz K., 1985, Język i poznanie, t. 1-2, Warszawa: PWN.

Bogustawski A., 1977, Problems of the Thematic-Rhematic Structure of Sentences, Warszawa: PWN.

Chalmers A. F., 1993, Czym jest to, co zwiemy nauka? Rozważania o naturze, statusie i metodach nauki, Wrocław: Wydawnictwo Siedmioróg.

Grochowsкi M., 2009, Miejsce partykuł w systemie części mowy. Historia i współczesność (na przykładzie języka polskiego), Sprawozdania z czynności i posiedzeń Polskiej Akademii Umiejętności LXXI (2007), s. 20-37.

Grochowsкi M., 2011, Zenona Klemensiewicza koncepcja składnika wypowiedzenia w świetle współczesnej składni semantycznej, w: Zenon Klemensiewicz (1891-1969), Kraków: Wydawnictwo PAU, s. 35-46.

Kallas K., 1961, Metaforyka wierszy Juliana Przybosia, Językoznawca 6, s. 67-75. 
Kallas K., 1974, Formalnogramatyczna klasyfikacja zdań pojedynczych dzisiejszej polszczyzny pisanej, Warszawa-Poznań: Bydgoskie Towarzystwo Naukowe.

Kallas K., 1978, Struktura syntaktyczna polskich konstrukcji apozycyjnych, Slavia Orientalis XXVII, z. 3, s. 345-350.

Kallas K., 1980, Grupy apozycyjne we współczesnym języku polskim, Toruń: Wydawnictwo Uniwersytetu Mikołaja Kopernika.

Kallas K., 1984, Słowotwórstwo przymiotników, w: R. Grzegorczykowa, R. Laskowski, H. Wróbel (red.), Gramatyka wspótczesnego języka polskiego. Morfologia, Warszawa: PWN, s. 408-455.

Kallas K., 1989, Polskie konstrukcje współrzędne jednorodne leksykalnie, w: Z. Saloni (red.), Studia z polskiej leksykografii wspótczesnej III, Białystok: Dział Wydawnictw Filii UW w Białymstoku, s. 235-258.

Kallas K., 1991, Jednorodność polskich konstrukcji współrzędnych, w: M. Grochowski, D. Weiss (red.), Words are physicians for an ailing mind, München: Verlag Otto Sagner, s. 257-264.

Kallas K., 1993, Składnia współczesnych polskich konstrukcji wspótrzędnych, Toruń: Wydawnictwo Uniwersytetu Mikołaja Kopernika.

Kallas K., 1994, Syntaktyczne cechy spójnika i partykuły ani, Polonica XVI, s. $103-125$.

KalLas K., 1995, O konstrukcjach z przyimkiem niż, w: M. Grochowski (red.), $W y$ rażenia funkcyjne w systemie i tekście, Toruń: Wydawnictwo Uniwersytetu Mikołaja Kopernika, s. 99-110.

Kallas K., 1997a, Rola czynników semantycznych w strukturze polskich konstrukcji porównawczych (z konektorem niż), Biuletyn Polskiego Towarzystwa Językoznawczego LII, s. 135-145.

Kallas K., 1997b, Składnia zdań porównawczych. Uwagi o zdaniach zespolonych spójnikiem niż, Polonica XVIII, s. 11-27.

Kallas K., 1998a, On Polish syntactic construction with the conjunction niz 'than', w: M. Grochowski, G. Hentschel (red.), Funktionswörter im Polnischen, Oldenburg: BIS, s. 195-218.

Kallas K., 1998b, Zaimki przeczące w polskim zdaniu, Prace Filologiczne XLIII, s. $229-235$.

KarolaK S., 1972, Zagadnienia sktadni ogólnej, Warszawa: PWN.

Karolak S., 2002, Podstawowe struktury składniowe języka polskiego, Warszawa: Slawistyczny Ośrodek Wydawniczy.

Kunn T., 1968, Struktura rewolucji naukowych, Warszawa: PWN.

Linde-Usiekniewicz J., 2008, Semantyka strukturalna w XXI wieku? w: P. Stalmaszczyk (red.), Metodologie językoznawstwa. Wspótczesne tendencje i kontrowersje, Kraków: Wydawnictwo Lexis, s. 158-173. 
Lyons J., 1977, Semantics, t. 1-2, Cambridge: Cambridge University Press.

Misz H., 1962, O tzw. psychologicznej analizie zdania, Zeszyty Naukowe UMK. Filologia Polska 3, s. 3-9.

Misz H., 1966, Jedna z zasad szyku wyrazów we współczesnym zdaniu polskim, Zeszyty Naukowe UMK. Filologia Polska 6, s. 3-68.

Misz H., 1967, Opis grup syntaktycznych dzisiejszej polszczyzny pisanej, Bydgoszcz: Bydgoskie Towarzystwo Naukowe.

Misz H., 1968, Podstawy klasyfikacji polskich zdań pojedynczych, w: Otázký slovanské syntaxe II, Brno: Universita J. E. Purkyně, s. 221-227.

Misz H., 1981, Studia nad składnia współczesnej polszczyzny pisanej, Toruń: Uniwersytet Mikołaja Kopernika.

Moroz A., Wiśniewsin M. (red.), 2004, Studia z gramatyki i semantyki języka polskiego, Toruń: Wydawnictwo Uniwersytetu Mikołaja Kopernika.

PoPPER K. R., 1977, Logika odkrycia naukowego, Warszawa: PWN.

Popper K. R., 1992, Wiedza obiektywna, Warszawa: PWN.

SAlONi Z., 1976, Cechy składniowe polskiego czasownika, Wrocław: Ossolineum.

SAloni Z., 1977, Kategorie gramatyczne liczebników we współczesnym języku polskim, Studia gramatyczne I, s. 145-173.

SAlONi Z., ŚwidZIŃSKi M., 1985, Składnia współczesnego języka polskiego, Warszawa: PWN.

SAussure de F., 1991, Kurs językoznawstwa ogólnego, Warszawa: PWN.

SAussure De F., 2004, Szkice z językoznawstwa ogólnego, Warszawa: Wydawnictwo Akademickie Dialog.

Szumska D., 2010, Odnowa czy od nowa...? Semantyka leksykalna w perspektywie tzw. zwrotu empirycznego w językoznawstwie XXI wieku, Linguistica Copernicana 1 (3), s. 129-140.

Świdziński M., 1978, Przykładowe transformacje w języku polskim, Polonica IV, s. $15-37$.

Wajszczuk J., 1997, System znaczeń w obszarze spójników polskich. Wprowadzenie do opisu, Warszawa: Katedra Lingwistyki Formalnej UW.

WAJszczuk J., 2005, O metatekście, Warszawa: Katedra Lingwistyki Formalnej UW.

Willim E., 2010, O sporach wokół formy i funkcji we współczesnym językoznawstwie. Formalizm kontra funkcjonalizm?, Linguistica Copernicana 1 (3), s. $81-127$. 


\section{Between semantic and non-semantic syntax. On Henryk Misz's and Zygmunt Saloni's influence on Krystyna Kallas's syntactic views \\ ( su m mary)}

Professor Krystyna Kallas, an excellent scholar, has been researching Polish syntax for nearly fifty years. She has published three monographs and several dozen papers concerned with the syntax of modern Polish. In the author's opinion, it is possible to define her works as placed between semantic and non-semantic syntax. The main purpose of the article is to show how the first period of Krystyna Kallas's scientific activity was influenced by Henryk Misz's works, whereas the second one by these of Zygmunt Saloni. 
